\title{
The Evolution of the \\ Des Moines Police Department: \\ Professionalization and the Decline of Public \\ Disorder Arrests in the Twentieth Century
}

\section{DOUGLAS WERTSCH}

During the twentieth Century the Des Moines police department evolved from a small, loosely organized force intent on maintaining public order to a complex bureaucracy dedicated to protecting the public from serious crime. Each year officers of the city's police department, like police officers throughout the country in the same years, made fewer arrests for public disorder offenses such as public drunkenness, vagrancy, and disturbing the peace by fighting or gambling.

Did the national decline in public disorder arrests reflect a "rise of urban order," as Eric Monkonnen claims?' That is, did citizens exhibit criminal or socially unacceptable behavior less and less frequently over the course of the nineteenth and twentieth centuries? Eugene Watts, in his case study of St. Louis, says no. He attributes the decline in public disorder arrests instead to a combination of change in the perception of crime and a simultaneous methodological change in policing that occurred during the twentieth century. ${ }^{2}$

Historians have traced the advent of police professionalism to the 1920 s and 1930s, when American police departments increased minimum employment standards, inaugurated continuing education programs, and developed modern personnel

1. Eric H. Monkkonen, "A Disorderly People? Urban Order in the Nineteenth and Twentieth Centuries," Journal of American History 68 (December 1981), 539-59.

2. Eugene J. Watts, "Police Response to Crime and Disorder in Twentieth Century St. Louis," Journal of American History 70 (September 1982), 304-58. 
management techniques. ${ }^{3}$ Other organizational and technical changes, including task specialization and improved firearms, electronic communication, and transportation, occurred in American police departments between 1945 and $1960 .^{4}$

In the process of professionalization, police departments tended to evolve through three successive types-service, watchman, and legalistic departments-each marked by increasing adherence to the letter of the law in deciding enforcement policies. ${ }^{5}$ At one end, the service department places a high value on maintaining public order, operates with a loose organization, and enjoys a close rapport with the public. At the other end, the legalistic department is characterized by strict adherence to the letter of the law and by a tight, complex organization that places a premium on specialization of functions within the department.

The experience of the Des Moines police department in the twentieth century, as it evolved from a service department to a legalistic department, confirms and illuminates this developmental model. The events that contributed to this transformation also make it clear that it was this process of change, and not a "rise of urban order," that caused a decline in public disorder arrests.

IN THE FIRST DECADE $_{\text {of the twentieth century, the Des Moines po- }}$ lice department was a typical service department. It maintained a high rate of public disorder arrests, but was not especially zealous in its attitude toward enforcing the law. The detective division represented the only area of specialization within the department. This organization provided a police force for the city

3. Nathan Douthit, "Police Professionalism and the War Against Crime in the United States, 1920s-30s," in Police Forces in History, ed. George L. Mosse (Beverly Hills, 1975), 317-33.

4. Eugene J. Watts, "Cops and Crooks: The War At Home," in Reshaping America: Society and Institutions, 1945-1960, ed. Robert H. Cremmer and Gary W. Reichard (Columbus, Ohio, 1982), 283-314.

5. James W. Wilson, Varieties of Police Behavior: The Management of Law and Order in Eight Communities (Cambridge, Mass., 1968). In a case study of a midwestern city, Theodore N. Ferdinand, "From a Service to a Legalistic Style Police Department: A Case Study," Journal of Police Science and Administration 4 (1976), 302-19, confirms the validity of this developmental model. 
during the time when the city underwent considerable changes in municipal operations.

On January 21,1896 , the state legislature granted the city of Des Moines a new charter that allowed the city to absorb the eight towns surrounding it, greatly expanding its geographic boundaries. ${ }^{6}$ Then in 1908 the city auditor issued the first annual report of the city under authority of the new "Des Moines Plan" of municipal government. Under the Des Moines Plan the commissioner of public safety appointed the chief of police (called the city marshal until 1912). The chief was solely responsible to and received instructions from the commissioner of public safety, thus freeing him from the influence of other city administrators, including the mayor. ${ }^{7}$

The police department was loosely structured at the turn of the century. It consisted of only two divisions: patrol (of which the detectives were a part) and administration (of which the jail was a part). Of the 87 officers in the department, 61 were assigned to foot patrol, 9 worked as detectives, and the remainder were supervisors. Personnel records prior to 1910 are incomplete, but it appears that the office of the chief of police changed hands frequently in the first decade of the twentieth century. Otherwise, except for a gradual increase in the number of officers who were assigned to foot patrol duty, personnel changes were slight.

As a service department, its police officers were concerned primarily with maintaining public order. This concern is reflected in the high arrest totals for public disorder offenses. The annual reports of the chief of police show 4,618 arrest for public disorder offenses in 1910, or 53 arrests per one thousand population, and 6,174 arrests, or 71 per thousand, in 1912. Reports in the Des Moines Register \& Leader, along with the increase in the department's budget allotment from $\$ 86,310$, when the new plan of government was initiated in 1908 , to $\$ 90,576$ in 1910 ,

6. Des Moines, City Auditor, Annual Report, 1908. Each city department including the police, submitted its annual report to the city council through the auditor, who collected these reports and bound them into a single document.

7. The plan was nationally acclaimed as a model for reform of municipal governments. Composed of five commissioners, each in control of a specific area of municipal service, it was seen as a way of eliminating politics from local government. 
suggest that this policy had the support of the public and the press. $^{8}$

Des Moines Police Department Statistics, 1900-1970

\begin{tabular}{|c|c|c|c|c|c|}
\hline Year & $\begin{array}{l}\text { Public } \\
\text { Disorder } \\
\text { Arrests* }\end{array}$ & $\begin{array}{c}\text { Felony } \\
\text { Arrests* }\end{array}$ & $\begin{array}{l}\text { Larceny } \\
\text { Arrests* }\end{array}$ & $\begin{array}{l}\text { Annual } \\
\text { Budget }\end{array}$ & $\begin{array}{l}\text { Annual } \\
\text { Salary } \\
\text { (mean) }\end{array}$ \\
\hline 1900 & 67 & 1.15 & 3.23 & - & - \\
\hline 1910 & 53 & 0.82 & 2.95 & 90,576 & $\$ 903^{* *}$ \\
\hline 1920 & 14 & 0.64 & 1.81 & 238,908 & - \\
\hline 1930 & 16 & 0.69 & 1.45 & 310,855 & 1,742 \\
\hline 1940 & 27 & 3.17 & 10.64 & 317,500 & 1,904 \\
\hline 1950 & 22 & 3.15 & 8.82 & - & - \\
\hline 1960 & 21 & 6.76 & 18.34 & $1,479,249$ & 5,010 \\
\hline 1970 & 25 & 11.48 & 35.86 & $4,006,381$ & - \\
\hline
\end{tabular}

SourCE: Des Moines, City Auditor, Annual Reports

* per one thousand population

**1908

BETWEen 1910 and 1920 the Des Moines police began to change from a service to a legalistic department. Public disorder arrests fell dramatically, from 53 to 14 arrests per one thousand population (see table). The administration's decision in 1911 to begin placing patrol officers in automobiles contributed to the decline in the number of public disorder arrests. Officers in automobiles are less likely to see public disorder violators because part of their attention is necessarily drawn to operating the vehicle, and even when officers in automobiles see public disorder violations they are less likely to make arrests due to the complications involved in parking the vehicle and leaving it while making the arrest. A vigorous and highly publicized police campaign against illegal sale of liquor, by both bootleggers and druggists, also contributed to the sudden drop in the number of public disorder arrests. ${ }^{9}$ As police supervisors pulled officers from routine patrol duty to augment this special enforcement drive, fewer officers were left on patrol to observe public disorder violators. The special attention the enforcement drive against bootlegging re-

8. The Des Moines Register \& Leader was published under a variety of titles. For simplicity it will be referred to hereafter as the Register (its current title). All citations refer to the front page of the newspaper. For an example of praise for the police department, see the issue of 4 January 1907.

9. Des Moines, City Auditor, Annual Reports, 1909-1915. 
ceived from the Des Moines Register foreshadowed later developments in the relationship between the police and the press. ${ }^{10}$ The ability of the local press in Des Moines to shape the perceptions and response of the police became more evident during the war years.

With the coming of World War I, the Register changed its method of using headlines. This eventually had important implications for the way law enforcement was carried out in Des Moines. Public anxiety and excitement over the Great War caused a huge increase in newspaper sales across the country. In response, the Register began using banner headlines to flag its stories covering the war. After the war the Register kept the headline format to counter competition from the other newspapers in town. In the spring of 1919 the Register carried a secondary headline about a local crime story. A year later the Register completed a major policy switch when a local crime story appeared under a page-one banner headline, "Wounded Thugs Confess Robberies." 11 That was the first time a routine crime received so much attention from the Register. Bill Millhaen, a reporter for the Register at the time, explained the cause for the policy change.

The real battle in those days was in street sales. That's where the news department could help most. We manufactured headlines that would sell papers on the street. If we didn't have a good story, we were expected to make one, magnify, or expand one. The final edition ... had to have headlines that the newsboys could merchandise. We built up feature stories as well as crimes of violence and tales of misfortune. If you could tie into a big headline, the paper would sell. ${ }^{12}$

From that time on the Des Moines police department's perception of crime was a key factor in its response to public offenses.

THE DEPARTMENT'S PERCEPTION of crime, not the actual commission of crimes, changed in the 1920s. Throughout the decade, public disorder arrests remained low compared to totals posted

10. Register, 5 and 7 January 1907, 28 February 1907, 2 January 1913.

11. Register, 22 May 1919, 3 May 1920.

12. George Mills, Harvey Ingham and Gardner Cowles, Sr: Things Don't Just Happen (Ames, 1977), 67. 
by the department between 1907 and 1919. The department's perception of a rampant crime problem, promoted by the Register, accounts for these low public disorder arrest totals. Officers began actively searching for "real" criminals such as burglars and robbers at the expense of continuing to seek out public disorder violators such as intoxicated pedestrians.

Other changes taking place nationally were also felt in Des Moines. The twin notions of police professionalism and a "war against crime" first began to gain wide acceptance during the 1920 s. In the months following the armistice of November 1918, American newspapers reported a sudden "crime wave." Des Moines was not immune. Although a large portion of the news reflected America's concern over the Bolshevik assumption of power, and news from Europe still claimed a large portion of space in the Register, crime stories now began appearing routinely on page one for the first time. ${ }^{13}$

The reaction to this perceived crime wave was swift. Between 1919 and 1929 crime commissions were organized across the country. By the end of the decade four states had established crime commissions or conducted crime surveys. The federal government created two crime commissions during this period: in 1925 President Calvin Coolidge established the National Crime Commission; four years later President Herbert Hoover set up a commission to investigate enforcement of prohibition laws. The latter, known officially as the National Commission on Law Observance and Enforcement, was remembered as the Wickersham Commission. This commission decided that in order to fully understand the state of prohibition enforcement it must first understand the criminal justice system at large. This came to mean not only police but corrections, the courts, parole, and probation, as well as prohibition enforcement. ${ }^{14}$ Mark O. Prentiss, an ex-journalist member of the Wickersham Commission, popularized the expression "war against crime" in 1925 when he wrote an article entitled "War On The Growing Menace of Crime" in which he explained the work of the commission.

The "war against crime" notion became increasingly popular in Iowa, too. In 1925 alone there were twenty-six successful

13. Register, 15 and 21 May, 8 June 1919.

14. Douthit, "Professionalism," 318. 
bank robberies and thirty unsuccessful attempts; losses totaled $\$ 258,000$. At the urging of the State Bankers Association, authorities deputized 4,200 men that year to patrol the streets near banks as well as to serve as a posse in the event of a bank robbery. The next year there were only three successful bank robberies out of a total of eight attempts recorded in lowa. This demonstrated, to the satisfaction of the bankers at least, that a "war against crime" could be "won." The Register reported all of these events, of course. At the same time local crime stories received increasing attention. In just the first two weeks of January 1925 , six banner headlines called the public's attention to local crime stories. ${ }^{15}$

In Des Moines, as elsewhere, the effect of this new emphasis was a heightened interest in the role of the police. Police began to see the control of crime as their primary function. Still, three categories of crime-murder, burglary, and robberyremained nearly constant during the decade. ${ }^{16}$ And arrests for larceny actually showed a decrease from 1.81 arrests per one thousand population in 1920 to 1.45 per thousand in 1930 . Clearly, it was the police department's perception of their role that changed, rather than the actual incidence of crime.

A shifting perception of crime was one factor contributing to Des Moines's static rate in public disorder arrests during the 1920s; the introduction of a medical detoxification unit was another. ${ }^{17}$ In January 1925 the Welfare Department of the Des Moines Chamber of Commerce began accepting intoxicated indigents for treatment. Officers did not arrest intoxicated persons who were transported to this detoxification unit, so such disorder arrests naturally declined.

The officers' new role as crime fighters also meant that they would spend less time and effort on public disorder offenders. A prerequisite for the change to a legalistic model of policing had been met by the Register's emphasis on crime stories. Public dis-

15. Register, 4, 5, 7, 10, 11, and 13 January 1925.

16. A felony is any crime that carries a penalty of at least one year's imprisonment. The categories of murder, burglary, and robbery were selected because of the impact they have on the public. These three categories have an intimate emotional impact on victims. As such they provide a solid gauge of the public's perception of crime in their community.

17. Register, 9 January 1925. 
order arrests remained static as the department concentrated on the "real" crime to which the Register was devoting so much attention.

Ironically, during a period of static arrest levels and only modest population growth, the department's power increased significantly. Between 1910 and 1930 the police department's personnel nearly doubled. To pay for this huge increase in the number of officers, the department's annual budget tripled from its 1910 allocation of $\$ 90,576$ to $\$ 310,855$ in $1930 .{ }^{18}$ Officers' annual pay also rose from $\$ 903$ to $\$ 1,742$ during this time. Because salary and prestige are closely related, it seems clear that the public's appreciation of its police had risen, too. It also seems clear that the department's increased power and status were due to the perception, not the reality, of increased crime in Des Moines.

DuRING THE 1930s, however, Des Moines had a genuine crime wave: public disorder arrests increased from 16 to 27 arrests per one thousand population, while felony arrests skyrocketed and larceny arrests multiplied more than sevenfold. The increase in larceny arrests drew the Des Moines police department's attention further away from public disorder offenders. The crime wave the Des Moines Register had reported in the 1920s actually came to pass in the 1930s.

Near the end of the 1920s the police department had gained new leadership. Chief A. H. Alber and Assistant Chief Roger West led the department from 1928 to 1938, providing for the first time the continuity necessary to establish policy and program on a long-term basis. The policy and program these men implemented was reform. To Alber and West reform meant more and better equipment, an emphasis on greater control of police personnel by the chief and his lieutenants, and vigorous pursuit of criminals committing felony class crimes such as burglary and robbery.

The reform movement received new impetus in the 1930s from Washington, D.C. In December 1934 President Franklin Roosevelt's attorney general, Homer Cummings, sponsored a conference on crime, marking a switch for the federal govern-

18. Des Moines, City Auditor, Annual Report, 1930. 
ment from encouraging to leading the war against crime. Throughout the 1930s J. Edgar Hoover, director of the Federal Bureau of Investigation, hammered home the theme of a war against crime. ${ }^{19}$ Director Hoover saw his Federal Bureau grow from 772 men in 1934 to 4,370 men in 1940 . By that time the FBI's budget was well over three million dollars. The FBI worked closely with local police, and for the next four decades their example provided a model for local of ficers to imitate.

As part of Chief Alber's reform program the department installed a one-hundred-watt radio transmitter (station KGZG) at police headquarters in September 1932. The cost of this new equipment was shared by the city's Junior Chamber of Commerce. At the same time the department installed radio receivers in twenty of its twenty-nine automobiles. Patrol officers then could receive continual broadcasts from a police dispatcher without stopping to call headquarters from a corner call box. In 1935 radio transmitters were placed in all of the department's automobiles, eliminating the need for using call boxes for routine communications.

Chief Alber also started a program of traffic safety following the recommendations of the Bureau of Traffic Research of Yale University. With the aid of fraternal and labor organizations, the police department established a motor vehicle testing station where vehicles could be inspected for a fifty-cent fee and receive a decal to indicate that the vehicle had been tested for safety. This became a popular way of checking the condition of used cars by potential buyers. Soon the city traffic department was inspecting a yearly average of 39,000 automobiles. The city used the money that was collected to cover the operating costs of the facility as well as to purchase new street signs. ${ }^{20}$

Organizational changes in the 1930s continued the trend toward a legalistic model of police enforcement. In the early 1920 s the department had two divisions; by the end of the decade two more had been added. Then, in the 1930s five moretraffic, vice, identification bureau, liquor bureau, and jail matrons-were added to the organizational table, which already included the jail, administration, detective, and patrol

19. Douthit, "Professionalism," 326.

20. Des Moines, City Auditor, Annual Reports, 1933 and 1935. 
divisions. ${ }^{21}$ In 1935 the Des Moines police department had 28 detectives and a total of 151 officers. There were two new job classifications, detective sergeant and detective lieutenant, and in 1939 the department added another assistant chief of police. ${ }^{22}$ These new job classifications continued the process of creating a more complex organization for the department.

By the close of the 1930s the Des Moines police department had erected the attitudinal and organizational components necessary to switch from a service to a legalistic model of policing. Nine divisions existed where before there had been only two. Twelve officers had been added to the department for a total of 160 (up from 148 in 1930). The average annual salary was up from $\$ 1,742$ in 1930 to $\$ 1,904$, and the department's annual budget had increased to a new high of $\$ 317,500$.

The effects of the Second World War and its aftermath dominated the 1940s in Des Moines. For the police department this was a period of relative quiet; arrests for all categories of crime were down from prewar years. Public disorder arrests continued to fall throughout the period, from 27 arrests per one thousand population in 1940 to 22 per thousand in 1950. Meanwhile, felony arrests remained constant. Even the category of larceny, which had posted such an explosive increase between 1930 and 1940, dropped from 10.64 arrests per one thousand population in 1940 to 8.82 per thousand in 1950 .

The city's census showed another modest population increase during the 1940 s, from 159,819 in 1940 to 177,956 in 1950. The department was able to continue to increase its staff, reaching a total of 171 members by 1945, in spite of repeated complaints in the annual reports of the loss of trained men to the armed forces. In 1944 alone thirteen men left the traffic bureau to join the armed forces. ${ }^{23}$

The switch from a service to a legalistic model of policing continued in the 1940s. The department eliminated foot beats except for a few square blocks in the center of the downtown business district. In 1940 the department dropped the job title "detective lieutenant"; the two men holding that position be-

21. Here division means subunit of a larger whole.

22. Des Moines, City Auditor, Annual Reports, 1935 and 1939.

23. Ibid., 1942-1945. 
came "inspectors" instead, and in 1944 three new inspectors were added. The detective division also underwent several reorganizations in the 1940s. In 1943 a special unit was created to investigate reports of subversives in Des Moines. Most of this information came from federal security organizations or other midwestern police departments. Also that year three new subdivisions-auto theft, forgery and bad check, and the pawn shop detail-were created.

A new juvenile unit was created in 1944, staffed by one lieutenant, one sergeant, five detectives, and two policewomen. Its assigned task was to work closely with other agencies in the community to counteract an expected rise in juvenile delinquency following the war. The unit also emphasized the war against crime, but from the angle of prevention, not apprehension. Closely allied to this new unit were the juvenile court, a Drake University professor, the chief probation officer of the juvenile court, and the pupil adjustment director of the school district, each of whom was informally and usually independently consulted as appropriate occasions arose. The group advised officers on cases and provided a reference service for juveniles and their parents, directing them to the social service agency most capable of providing the assistance they needed. ${ }^{24}$

Officer education became a concern for the department's leadership during the 1940s. In 1947 the department raised the minimum educational requirements for police applicants to two years of high school, and required supervisory officers above the rank of sergeant to attend, at city expense, the Federal Bureau of Investigation's National Police Academy. ${ }^{25}$ The leaders of the department were beginning to see themselves as professionals and were seeking professionally trained personnel to assume future leadership roles.

The Des Moines police department completed the transformation from a service to a legalistic model of policing in the 1940 s. The age of specialization, accompanied by a complex and tightly organized operation, had come. The department's determined pursuit of reform policy during a time of war demon-

24. Ibid., 1943 and 1944.

25. Register, 4 June, 25 September 1947. 
strates that it was the perception of crime, and not crime itself, that affected the department most profoundly.

The Des Moines police department continued to follow a legalistic model of policing throughout the 1950s. Howard Edie became chief of police in 1950. Under his leadership the department continued to pursue the twin themes of police reform and the war against crime.

In May 1950 a criminologist from the University of California-Berkeley arrived to advise the department on revamping its organization and operations. ${ }^{26}$ In August 1950 the department issued its first Rules and Regulations Manual detailing the duties, functions, and authorized responses of its officers to every situation it could imagine. ${ }^{27}$ The manual also outlined a streamlined chain of command, beginning at the top with the chief, that further centralized authority in the department.

In 1957 Chief Edie completely reorganized the department, establishing it even more firmly as a legalistic type of department. Four divisions-uniform, investigations, service, and administration-were constituted, each with its own assistant chief. One hundred twenty-four patrolmen served in the uniform division. Forty-five men and one woman were assigned to the investigation division, which included the detective unit, the vice unit, and the juvenile unit. The service division, staffed by forty-nine officers, contained the records unit, communication (radio dispatchers), the jail, and the crime laboratory. Finally, the chief plus seven senior supervisory officers made up the administration division. So by 1957 the number of nonpatrol officers (103) nearly equalled the number of officers (124) in traditional patrol assignments. Specialization, one of the hallmarks of a legalistic style police department, had become ingrained in the department's organization.

The number of public disorder arrests remained low in the $1950 \mathrm{~s}$. The three categories of felony arrests, however, doubled, as did larceny arrests. ${ }^{28}$ In 1958 the department's budget ex-

26. Register, 23 May 1950.

27. Register, 23 August 1950.

28. While some of this reported increase may be attributed to the more complete record keeping a legalistic department may be expected to maintain, this surely represents a quantitative leap in felony and larceny arrests during the period. 
ceeded one million dollars for the first time. By that time the average annual salary for patrol officers had increased to $\$ 5,010$, up from a prewar salary of $\$ 1,904 .^{29}$

A new interest in public relations emerged as a significant factor for the Des Moines police in the 1950s. As is typical of a legalistic department, much of the informal familiarity the department once had enjoyed with the public had dissipated. In an effort to recapture some of this lost public goodwill, the department began holding "open houses" for the public in the 1950s. In $1957,6,308$ citizens participated in small group tours or attended the annual "open house" at police headquarters. ${ }^{30}$

Training, as well as organizational changes, dominated the department's concerns in the 1950s. In 1957 a traffic sergeant won a nine-month fellowship to the Traffic Institute at Northwestern University. By that time the department had begun operating two fifty-six-day recruit schools, graduating twentytwo recruits each time. In 1959 the department began constructing its own police academy building. In the same year an assistant chief of police attended a twelve-week seminar on police science and procedures at the Southern Police Institute at Louisville University. Another assistant chief of police traveled to Michigan State University to attend a five-day course of instruction in police-community relations. Also in 1959 the department's library expanded from 56 to 134 books on sociology, psychology, criminology, and investigation techniques.

Other significant innovations also appeared in the 1950s. Forty-hour work weeks were introduced as a way of increasing the personal efficiency of the officers. Then, in an effort to free more officers for patrol duty while holding the line on personnel expenses, the department began employing meter maids and assigning just one officer to a car on patrol beats. ${ }^{31}$

The SAME Two THEMES - the war against crime, and police reform and professionalism - that had influenced developments in the Des Moines police department since the 1920s and 1930s continued to receive strong support within the department during

29. Des Moines, Office of Budget Publication, 1959. This publication details each city government bureau's appropriation.

30. Des Moines, City Auditor, Annual Report, 1957.

31. Register, 27 July 1951, 2 September 1950. 
the 1960 s. In 1960 a new subdivision, the research and development unit, was added under the service division. The first task of the unit was to investigate the need for a "board of inquiry," or civilian review board, composed of community notables who would judge, upon citizen complaint, the actions of individual officers. ${ }^{32}$ Also in 1960 the department sent an officer to the Keeler Polygraph Institute in Chicago. American police were becoming as fascinated with pseudoscientific gadgets as the rest of the population, and the Des Moines police proved no exception.

Reform also continued to mean increased specialization and reorganization upon reorganization. In 1962 sixty-seven officers enrolled in various schools outside the department for specialized training. The department's own police academy evolved during the 1960s into a six-week school with over fifty different subjects in the curriculum. In 1960 the city was divided into three patrol sections, each having four one-person patrol cars and a sergeant responsible for the area. The juvenile unit received permission to hire a policewoman with a college degree in either psychology or sociology. And in 1962 the investigation division was again reorganized. There were now six areas of specialization within that division: robbery/homicide, burglary, auto theft, vice, juvenile, and "general assignments."

The number of public disorder arrests remained low throughout the decade, while felony and larceny arrests took another dramatic leap. The department's annual budget increased from $\$ 1,479,249$ in 1960 to $\$ 4,006,381$ in 1970 , and the department's personnel total of 335 officers in 1970 (up from 234 in 1960) made the department the state's largest by a wide margin.

SeVERAL Forces account for the decline in public disorder arrests in Des Moines during the twentieth century. Beginning in the early 1920 s the Des Moines police department implemented a methodological change in policing that drew its attention away from public disorder offenses toward the more urgent task of protecting lives and property and apprehending felons. The Des Moines press, by using its power to conjure and control mass

32. There is no evidence that such a board was created at that time. 
perceptions of social conditions, provided the impetus for change. In reacting to the "crime wave" stories of the 1920 s and 1930 s the Des Moines police department altered its selfperceived role. By embracing the ideas of police professionalism and a war against crime, Chiefs Alber and Edie restructured the Des Moines police department in a way that enabled it to pursue "serious" crime aggressively rather than continue with the older idea of being the guardians of public order.

The decline in public disorder arrests during the twentieth century, then, does not indicate a "rise of urban order." While public disorder arrests fell from a high of 71 arrests per one thousand population in 1912 to nearly a third of that figure by 1970 , it is inaccurate to equate public disorder arrest data with urban order: This is especially true in Des Moines, where the felony arrest rate grew from a low of one arrest per one thousand population to nearly twelve times that figure by 1970 .

By 1970 Des Moines had a police department that clearly followed a legalistic style of policing. The three chief components of such a department-a complex organizational table, task specialization, and an emphasis on law enforcement over other forms of police service-were firmly established. Des Moines police had decided to switch from their role as keepers of public order to the more urgent task of protecting the public from serious crime. That decision, more than any other factor, accounts for the decline in public disorder arrests in Des Moines during the twentieth century. 
Copyright of Annals of Iowa is the property of State of Iowa, by \& through the State Historical Society of Iowa and its content may not be copied or emailed to multiple sites or posted to a listserv without the copyright holder's express written permission. However, users may print, download, or email articles for individual use. 